\title{
Effects of nutrition (herbivore vs carnivore) on energy charge and nucleotide composition in Hyas araneus larvae
}

\author{
J. Harms \\ Biologische Anstalt Helgoland, Marine Station; \\ $D$-W-2192 Helgoland, Federal Republic of Germany
}

\begin{abstract}
Growth rate expressed as dry weight, elemental composition (C, N, H), protein content and nucleotide composition (ATP, ADP, AMP, CTP, GTP and UTP) as well as adenosine were measured in laboratory cultured Hyas araneus larvae fed two different diets. One group was fed freshly hatched Artemia sp. nauplii, the other the diatom Odontella (Biddulphia) sinensis. Growth rate was reduced in the $O$. sinensis-fed group, reaching 20 to $50 \%$ of the growth rate of Artemia-fed larvae. In all cases, some further development to the next instar occurred when larvae were fed $O$. sinensis, although at reduced levels compared to Artemia-fed larvae. The adenylic energy charge was quite similar for the two nutritional conditions tested and therefore does not reflect the reduced growth rate in $O$. sinensis-fed larvae. The individual nucleotide content was clearly reduced in $O$. sinensis-fed larvae, reflecting the nutritional conditions already during early developmental periods. These reduced amount of nucleotides in $O$. sinensis-fed larvae were most obvious when adenylic nucleotide contents were pooled. Pooled adenylic nucleotides were found to be correlated with the individual content of carbon and protein, showing significant differences at both nutritional conditions tested.
\end{abstract}

\section{INTRODUCTION}

Adenylic energy charge (AEC) was first used as a measurement of the energy directly available to cells (Atkinson \& Walton, 1967; Bomsel \& Pradet, 1967), and it was later adopted by Ivanovici (1980a) and Romano \& Daumas (1981) as an index for estimating the physiological condition of organisms. A previous study of the nucleotide composition of decapod larvae showed that the AEC was generally unaffected by food conditions (Harms et al., 1990b). It was suggested in that study that the individual amount of adenylate nucleotides might be a more useful indicator of the well-being of decapod larvae, supporting Atkinson's original hypothesis that the AEC might be a relatively conservative property and that changes in AEC are always accompanied if not preceded by changes in the quantity of adenylate nucleotides (Atkinson, 1968). To evalute these previous results, the elemental composition, protein and nucleotide content of Hyas araneus larvae fed two different diets (herbivore vs carnivore) were analysed. The nutritional conditions used here have already been studied in more detail in previous reports (Harms \& Seeger, 1989; Harms \& Anger, 1990; Harms et al., 1990a). The two diets were chosen because of their difference in nutritional value, which facilitates the detection of variations in nucleotide content and/or AEC related to growth conditions. 


\section{MATERIALS AND METHODS}

\section{Handling of larvae}

Ovigerous females of Hyas araneus were collected near Helgoland (North Sea, German Bight). Females were maintained individually in flow-through aquaria until freshly hatched, actively swimming larvae could be collected in sieves which received water from an overflow. The larvae were reared in mass cultures (Zoea I: 50; Zoea II: 30 and Megalopa 10 individuals) at a constant temperature of $12^{\circ} \mathrm{C}$ in $1-\mu \mathrm{m}$-filtered natural seawater ( 30 to $32 \% \mathrm{~S}, 12 \mathrm{~h}$ light: $12 \mathrm{~h}$ dark) with two different diets. The data for each larval stage were collected from a larval hatch originating from one female. In order to obtain zoea II and megalopa stages, larvae were cultivated by standard methods using Artemia sp. nauplii as food (Anger et al., 1983), until they reached these stages. Each experiment (zoea I, II and megalopa) started with freshly moulted larvae (day zero of the experiment). In each experiment, larvae were divided into two groups. One group was fed freshly hatched Artemia sp. nauplii (Bay Brand, San Francisco, USA), the other diatoms Odontella (Biddulphia) sinensis. The food concentration in the Artemia-fed group was $\approx 10$ nauplii $\cdot \mathrm{ml}^{-1}=7.6 \mu \mathrm{g} \mathrm{C} \cdot \mathrm{ml}^{-1}$. The $O$. sinensis-fed group received a food concentration of $60 \mathrm{cells} \cdot \mathrm{ml}^{-1}=1 \mu \mathrm{g} \mathrm{C} \cdot \mathrm{ml}^{-1}$ (for more details see Harms et al., 1990a). The culture medium was changed daily for the $O$. sinensis and every second day for the Artemia-fed group.

\section{Biochemical analyses}

Larval growth and nucleotide composition were measured in each larval stage at regular intervals (every second day in zoea I and II, every third day in megalopa) in aliquot samples of larvae from the same hatch and of the same age within a given moult cycle. Samples were stored at $-80^{\circ} \mathrm{C}$ for later analyses. Parallel measurements comprised the following: dry weight $(\mathrm{W})$, carbon $(\mathrm{C})$, nitrogen $(\mathrm{N})$, and hydrogen $(\mathrm{H})$, protein and nucleotide composition. $\mathrm{W}, \mathrm{C}, \mathrm{N}$ and $\mathrm{H}$ were measured in eight replicates, with freeze drying weighing on a Mettler UM3 microbalance, and subsequent combusting in an Elemental Analyser Model 1106 (Carlo Erba Science), following the methods described by Anger et al. (1989).

In order to measure nucleotides and protein content, three replicate samples of 50 (Zoea I and II) to 20 (megalopa) larvae were homogenized in $1.5 \mathrm{ml}$ of cold $0.5 \mathrm{M}$ Trichloroacetic acid. The cooled samples stood $10 \mathrm{~min}$ for protein precipitation and nucleotide extraction before being centrifuged for $15 \mathrm{~min}$ at $4300 \mathrm{rpm}$. The supernatant was decanted and neutralized $(\mathrm{v} / \mathrm{v})$ with a mixture of Trioctylamin and Freon $(0.5 \mathrm{M})$. The water phase was used immediately after careful mixing for analysis of nucleotide content by HPLC (for details see Moal et al., 1989). In addition to the three adenylic nucleotides (AN) ATP, ADP and AMP, also CTP, GTP, UTP and adenosine could be detected in most cases. The pellet was resuspended in $1.0 \mathrm{ml} 1 \mathrm{~N} \mathrm{NaOH}$ and was left at $4^{\circ} \mathrm{C}$ for at least 12 $h$, before analysing total protein by the Folin Ciocalteau method (Lowry et al., 1951).

Artemia-fed megalopa were analysed twice. During the first experiment (Experiment I), no comparable data for $O$, sinensis-fed larvae could be obtained, because infections occurred in the algae cultures early in the experiment. Therefore, a second experiment (Experiment II) was performed. Experiment I is included in some figures 
when of special interest and marked as Experiment I. Experiment I data were also included in the data pool for regression analysis.

Error bars $(\overline{\mathrm{x}} \pm \mathrm{SD})$ are given in Tables and Figures only, when directly measured values are displayed, not in those calculated from two independently measured data series (for instance, nucleotide content $\cdot \mathrm{mg}$ protein $^{-1}$ (Table 2), AEC (Fig. 4) and $\Sigma$ AN (Fig. 5).

\section{RESULTS}

\section{Growth rate}

Larval growth was measured as dry weight (W), carbon (C), nitrogen (N), hydrogen $(\mathrm{H})$ and protein. $\mathrm{W}$ and protein content are given in Table 1 . The changes in absolute biomass per individual during the larval development is shown for $\mathrm{C}$ in Figure 1. Increase in $\mathrm{N}$ content is documented as total net gain during each larval instar (Fig. 2). The individual amount of $\mathrm{N}$ at both nutritional conditions can be estimated from the protein content by using the regression equation given by Anger et al. (1989). The individual content for $\mathrm{H}$, which is not presented here, might be estimated from $\mathrm{C}_{1}$ using the regression equation also given by Anger et al. (1989).

During each larval stage, $\mathrm{W}, \mathrm{C}, \mathrm{N}$ and protein increased under both nutritional conditions tested, except for protein in Odontella (Biddulphia) sinensis-fed megalopa (Fig. 2). The gain in organic material was highest in the Artemia-fed group, reaching slightly higher net gain values in W, C and N, compared to data presented by Harms et al. (1990a). The net gain in protein was low compared to earlier data (Harms et al., 1990a). The percentage gain of biomass decreased in Artemia-fed larvae from instar to instar. Larvae fed $O$. sinensis had a lower biomass increase compared to Artemia-fed larvae (Fig. 2). The absolute and percentage increase of biomass was highest in the zoea II, except for $W$ and protein which was accumulated in higher quantities in the megalopa and the zoea I, respectively. The biomass increase in the zoea I reached approximately one-fifth, except for protein which reached one-third, of the biomass accumulation of Artemia-fed larvae. The growth rate in the zoea II reached approximately 55 to $65 \%$ of the values of Artemia-fed larvae, except for protein which reached only $20 \%$. The biomass increase in $O$. sinensis-fed megalopa varied between $16 \%(\mathrm{C}), 36 \%(\mathrm{~N})$ and $53 \%(\mathrm{~W})$ compared to Artemia-fed megalopa. Protein decreased $(-9 \%)$ in the megalopa when fed $O$. sinensis. The net gain of biomass in $O$. sinensis-fed larvae reported here, is above the values reported in an earlier study (Harms et al., 1990a). This is especially true for $\mathrm{W}, \mathrm{C}$ and $\mathrm{N}$ in the zoea II and megalopa stages. Further development to the next larval instar could be observed in all experiments, although developmental success of $O$. sinensis-fed larvae was low compared with the Artemia-fed group. The developmental success of $O$. sinensis-fed larvae decreased from zoea I to megalopa.

The growth measured as W, protein and C (Table 1 and Fig. 1) ceased in all instars in late premoult. This final phase of constant or decreasing biomass is part of the normal growth pattern of the larvae, and is always much longer in the megalopa stage than in zoeal stages (see Anger et al., 1990). This decrease in biomass was observed earlier in the moulting cycle when larvae were fed with the diatom $O$. sinensis (Fig. 1). 
Table 1. Hyas araneus. Dry weight $\left(W, \mu \mathrm{g}\right.$ individual $\left.{ }^{-1}\right)$, and protein content $\left(\mu \mathrm{g}\right.$ individual $\left.{ }^{-1}\right)$ during time (days) of development in subsequent larval stages reared under different nutritional conditions at constant temperature $\left(12^{\circ} \mathrm{C}\right){ }^{\prime}$ Larvae developed to the next instar after being fed with Odontella (Biddulphia) sinensis in the previous larval stage; $\overline{\mathrm{x}}, \pm \mathrm{SD}$ : arithmetic mean, standard deviation; number of analyses $=8$ for $W_{1}=3$ for protein

\begin{tabular}{|c|c|c|c|c|c|c|c|c|c|}
\hline \multirow{3}{*}{$\begin{array}{l}\text { Larval } \\
\text { stage }\end{array}$} & \multirow{3}{*}{$\begin{array}{c}\text { Age } \\
\text { (days) }\end{array}$} & \multicolumn{4}{|c|}{ Dry weight } & \multicolumn{4}{|c|}{ Protein } \\
\hline & & \multicolumn{2}{|c|}{ Artemia sp. } & \multicolumn{2}{|c|}{ O. sinensis } & \multicolumn{2}{|c|}{ Artemia sp. } & \multicolumn{2}{|c|}{ O. sinensis } \\
\hline & & $\bar{x}$ & $\pm \mathrm{SD}$ & $\overline{\mathrm{x}}$ & $\pm \mathrm{SD}$ & $\overline{\mathrm{x}}$ & $\pm \mathrm{SD}$ & $\overline{\mathbf{x}}$ & $\pm \mathrm{SD}$ \\
\hline \multirow[t]{8}{*}{ Zoea I } & 0 & 68.46 & 2.07 & 68.46 & 2.07 & 19.17 & 1.66 & 19.17 & 1.66 \\
\hline & 2 & 108.96 & 5.46 & 87.75 & 1.93 & 25.64 & 1.65 & 19.36 & 2.33 \\
\hline & 4 & 105.70 & 3.58 & 102.75 & 5.15 & 31.63 & 0.62 & 24.47 & 2.85 \\
\hline & 6 & 140.81 & 3.68 & 112.02 & 6.50 & 37.16 & 0.47 & 31.73 & 5.03 \\
\hline & 8 & 145.02 & 11.80 & 121.49 & 17.30 & 47.72 & 3.09 & 32.11 & 2.82 \\
\hline & 10 & 170.26 & 12.10 & 89.27 & 3.30 & 44.09 & 1.37 & 30.81 & 1.50 \\
\hline & 12 & & & 95.99 & 6.37 & & & 30.16 & 1.65 \\
\hline & 14 & & & 102.86 & 3.78 & & & 27.64 & 1.98 \\
\hline Zoea II** & 0 & & & 145.80 & 6.31 & & & 34.89 & 1.61 \\
\hline \multirow[t]{9}{*}{ Zoea II } & 0 & 161.23 & 5.70 & 161.23 & 5.70 & 50.56 & 1.28 & 50.56 & 1.28 \\
\hline & 2 & 242.47 & 8.82 & 206.74 & 15.30 & 62.50 & 1.21 & 58.24 & 0.62 \\
\hline & 4 & 265.37 & 18.67 & 217.42 & 19.54 & 71.52 & 1.70 & 59.39 & 4.46 \\
\hline & 6 & 299.84 & 14.32 & 252.72 & 18.98 & 76.01 & 7.02 & 57.89 & 0.75 \\
\hline & 8 & 329.13 & 25.33 & 242.02 & 24.42 & 88.49 & 0.19 & 52.23 & 4.01 \\
\hline & 10 & 348.31 & 13.71 & 244.04 & 30.60 & 76.35 & 8.20 & 63.82 & 0.53 \\
\hline & 11 & 350.73 & 12.00 & 286.97 & 10.08 & 85.27 & 2.92 & 62.89 & 3.83 \\
\hline & 12 & 343.01 & 7.09 & 288.19 & 21.16 & 89.02 & 0.19 & 65.86 & 8.23 \\
\hline & 13 & & & 289.41 & 14.24 & & & 57.79 & 4.82 \\
\hline Megalopa.. & 0 & & & 278.24 & 15.42 & & & 72.13 & 0.51 \\
\hline \multirow[t]{9}{*}{ Megalopa } & 0 & 322.53 & 13.52 & 322.53 & 13.52 & 101.93 & 12.81 & 101.93 & 12.81 \\
\hline & 3 & 529.69 & 51.09 & 402.29 & 22.83 & 143.91 & 6.71 & 92.55 & 25.08 \\
\hline & 6 & 574.06 & 42.09 & 507.45 & 44.48 & 177.82 & 20.87 & 100.97 & 2.76 \\
\hline & 9 & 566.11 & 30.41 & 526.14 & 56.62 & 195.14 & 8.05 & 113.28 & 3.61 \\
\hline & 12 & 626.65 & 68.67 & 529.39 & 39.52 & 219.23 & 14.03 & 111.10 & 24.88 \\
\hline & 15 & 554.72 & 36.67 & 485.19 & 38.47 & 178.26 & 35.37 & 100.84 & 1.87 \\
\hline & 18 & 642.43 & 77.37 & 482.77 & 62.17 & 143.90 & 6.66 & 115.51 & 12.36 \\
\hline & 21 & 552.49 & 34.03 & 431.11 & 41.64 & 140.34 & 1.09 & 90.21 & 1.38 \\
\hline & 24 & 573.11 & 32.48 & 454.57 & 65.24 & 134.94 & 2.48 & 93.03 & 0.93 \\
\hline
\end{tabular}

\section{Nucleotide composition}

The nucleotide composition for both nutritional conditions tested is given in Table 2 as concentrations ' $\mathrm{mg}$ protein $^{-1}$. Besides the three adenosine nucleotides (AN), adenosine and the three triphosphates CTP, UTP and GTP could be detected. The column separation for UTP and GTP was sometimes inadequate and these analyses are marked with an asterisk. The protein specific nucleotide concentrations were very similar for both diets tested and stayed quite constant throughout each moulting cycle.

The individual AN content is given in Figure 3. The variation of the three replicates is normally below $5 \%$, so that error bars are not visible. Higher standard deviations are found in ATP analyses. The increase in ATP was most advanced in Artemia-fed larvae. 

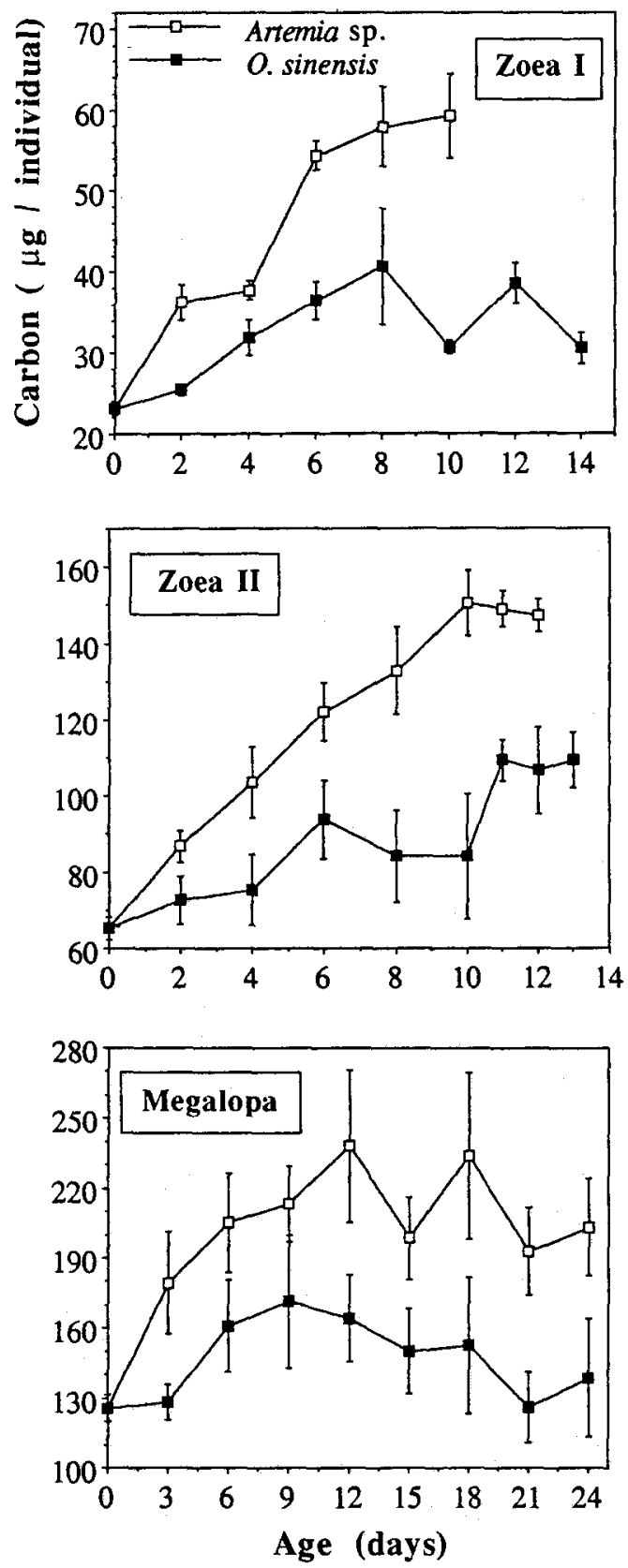

Fig. 1. Hyas araneus. Carbon content ( $\mu$ g $\cdot$ individual $^{-1} ; \mathrm{x} \pm \mathrm{SD}_{i} \mathrm{n}=8$ ) during the course of the moulting cycle in subsequent larval stages fed two different diets 
Table 2. Hyas araneus. Protein specific nucleotide (AMP, ADP, ATP, CTP, UTP, GTP) and adenosine concentrations during time (days) of development in subsequent larval stages reared under different nutritional conditions at constant temperature $\left(12^{\circ} \mathrm{C}\right)$. Analyses with inadequate separation. $\because$ Larvae developed to the next instar after being fed in the previous larval stage with Odontella (Biddulphia) sinensis

\begin{tabular}{|c|c|c|c|c|c|c|c|c|}
\hline $\begin{array}{l}\text { Larval stage/ } \\
\text { Diet }\end{array}$ & $\begin{array}{l}\text { Age } \\
\text { (days) }\end{array}$ & AMP & $\mathrm{ADP}$ & ATP & CTP & UTP & GTP & Adenosine \\
\hline \multicolumn{9}{|l|}{ Zoea I } \\
\hline \multirow[t]{6}{*}{ Artemia sp. } & 0 & 0.95 & 2.08 & 14.16 & 1.35 & 1.47 & 1.08 & - \\
\hline & 2 & 0.90 & 1.70 & 11.61 & 1.15 & $0.91^{*}$ & $1.70^{\circ}$ & 3.02 \\
\hline & 4 & 1.51 & 1.85 & 15.93 & 1.16 & 2.98 & 1.34 & 3.07 \\
\hline & 6 & 1.05 & 2.52 & 15.93 & 1.40 & 1.56 & 1.15 & 0.87 \\
\hline & 8 & 1.55 & 3.53 & 11.44 & 1.37 & 2.85 & 1.26 & 0.76 \\
\hline & 10 & 0.74 & 4.05 & 13.48 & 1.35 & 2.64 & 0.87 & 2.47 \\
\hline \multirow[t]{8}{*}{ O. sinensis } & 0 & 0.95 & 2.08 & 14.16 & 1.35 & 1.47 & 1.08 & - \\
\hline & 2 & 0.74 & 1.92 & 10.84 & - & 1.24 & 0.94 & - \\
\hline & 4 & 0.97 & 1.87 & 13.24 & 1.04 & 2.13 & 1.29 & 1.54 \\
\hline & 6 & 1.47 & 2.84 & 12.34 & 1.41 & 1.83 & 1.13 & 0.97 \\
\hline & 8 & 0.87 & 3.70 & 10.60 & 1.68 & 2.08 & 1.12 & 2.11 \\
\hline & 10 & 0.74 & 3.92 & 10.86 & 1.08 & $1.78^{\circ}$ & $0.75^{\circ}$ & 2.30 \\
\hline & 12 & 0.94 & 1.75 & 13.37 & 1.41 & 2.05 & 1.13 & - \\
\hline & 14 & 0.35 & 1.18 & 14.02 & 0.98 & 1.05 & 0.84 & 0.88 \\
\hline Zoea II** & 0 & 1.46 & 3.94 & 10.77 & 2.28 & 0.99 & 0.69 & - \\
\hline \multicolumn{9}{|l|}{ Zoea II } \\
\hline \multirow[t]{8}{*}{ Artemia sp. } & 0 & 1.82 & 2.95 & 12.34 & 0.94 & 1.45 & 1.02 & 0.55 \\
\hline & 2 & 2.38 & 2.64 & 14.91 & 2.58 & 2.01 & 1.28 & 0.54 \\
\hline & 4 & 1.25 & 2.42 & 12.45 & 1.80 & 4.43 & 1.06 & - \\
\hline & 6 & 0.97 & 2.64 & 16.06 & 2.96 & $6.02^{\circ}$ & $1.55^{\circ}$ & 0.45 \\
\hline & 8 & 1.11 & 2.10 & 15.40 & 0.50 & $5.82^{*}$ & $1.26^{\circ}$ & 0.37 \\
\hline & 10 & 1.60 & 2.59 & 17.29 & 1.53 & 1.49 & 1.22 & 0.48 \\
\hline & 11 & 0.91 & 2.09 & 16.93 & 1.10 & 4.21 & 1.47 & 0.40 \\
\hline & 12 & 0.92 & 1.05 & 14.27 & 0.78 & 3.13 & 1.25 & 0.77 \\
\hline \multirow[t]{9}{*}{ O. sinensis } & 0 & 1.82 & 2.95 & 12.34 & 0.94 & 1.45 & 1.02 & 0.55 \\
\hline & 2 & 1.30 & 2.52 & 12.89 & 2.61 & 2.54 & 1.06 & - \\
\hline & 4 & 1.52 & 2.89 & 12.99 & 2.58 & 2.91 & 1.07 & - \\
\hline & 6 & 2.24 & 3.60 & 16.69 & 2.85 & 3.75 & 1.36 & 0.60 \\
\hline & 8 & 1.69 & 2.86 & 15.73 & 1.58 & 3.43 & 1.56 & 0.65 \\
\hline & 10 & 1.29 & 3.63 & 16.44 & 1.51 & 3.43 & 1.41 & 0.57 \\
\hline & 11 & 1.28 & 1.42 & 17.74 & 0.97 & 4.22 & 1.59 & 0.81 \\
\hline & 12 & 1.58 & 2.75 & 14.29 & 0.69 & - & - & 0.91 \\
\hline & 13 & 2.33 & 4.75 & 14.43 & 0.46 & 2.33 & 0.39 & 1.04 \\
\hline Megalopa** & 0 & 2.47 & 3.01 & 11.54 & 0.54 & 1.75 & 1.20 & 0.82 \\
\hline \multicolumn{9}{|l|}{ Megalopa } \\
\hline \multirow[t]{9}{*}{ Artemia sp. } & 0 & 1.65 & 1.70 & 11.42 & 0.57 & 1.56 & 0.91 & 1.21 \\
\hline & 3 & 1.39 & 1.26 & 9.73 & 0.82 & 1.89 & 0.78 & 1.22 \\
\hline & 6 & 1.12 & 1.18 & 11.42 & 0.74 & 2.30 & 0.88 & 1.19 \\
\hline & 9 & 1.04 & 1.23 & 10.96 & 0.93 & 1.95 & 0.82 & 0.68 \\
\hline & 12 & 4.19 & 3.37 & 4.64 & 0.99 & 0.87 & 0.48 & 0.52 \\
\hline & 15 & 0.95 & 1.01 & 12.43 & 0.90 & 2.48 & 0.91 & 0.41 \\
\hline & 18 & 1.33 & 1.86 & 15.18 & 0.96 & 2.51 & 1.09 & 0.75 \\
\hline & 21 & 3.32 & 4.00 & 10.54 & 0.99 & 1.49 & 0.78 & 0.61 \\
\hline & 24 & 1.66 & 2.34 & 15.01 & 1.03 & 1.89 & 1.07 & 1.14 \\
\hline
\end{tabular}


Table 2 (contd)

\begin{tabular}{|lrrrrrrrr|}
\hline $\begin{array}{l}\text { Larval stage/ } \\
\text { Diet }\end{array}$ & $\begin{array}{c}\text { Age } \\
\text { (days) }\end{array}$ & AMP & ADP & ATP & CTP & UTP & GTP & Adenosine \\
\hline Megalop a & & & & & & & & \\
O. sinensis & 0 & 1.65 & 1.70 & 11.42 & 0.57 & 1.56 & 0.91 & 1.21 \\
& 3 & 1.94 & 1.82 & 10.87 & 0.74 & 1.15 & 0.84 & 0.63 \\
& 6 & 2.10 & 1.69 & 20.71 & 1.03 & 3.86 & 1.50 & 0.81 \\
& 9 & 2.85 & 3.51 & 11.01 & 0.90 & 1.47 & 0.90 & 0.70 \\
& 12 & 1.66 & 2.54 & 19.31 & 0.84 & 2.76 & 1.13 & 0.62 \\
& 15 & 1.34 & 2.14 & 17.80 & 1.36 & 2.97 & 1.26 & 0.75 \\
& 18 & 1.11 & 2.30 & 16.42 & 0.43 & 2.43 & 1.33 & 0.60 \\
& 21 & 1.40 & 2.60 & 16.39 & 0.67 & 1.18 & 1.18 & 0.84 \\
& 24 & 10.27 & 5.68 & 3.05 & 1.33 & 0.68 & 0.43 & 0.79 \\
\hline
\end{tabular}

Experiment I and II on Artemia-fed megalopa showed similar nucleotide contents during the larval development, except for 12-day old megalopa in Experiment II. A net gain of ATP was also found in the $O$. sinensis-fed larval stages. However, the individual amount of nucleotides in $O$. sinensis-fed larvae were always reduced compared to Artemia-fed larvae. This trend was already established during early developmental processes, showing that nutritional conditions had an immediate influence on the levels of nucleotides and therefore on the energy available to the larvae. The percentage proportion of ATP to the total AN pool varied with a few exceptions between 75 to $92 \%$, under both nutritional conditions tested.

The adenylic energy charge (AEC) was calculated from the mean values of individual AN content presented in Figure 3. In zoea I, AEC decreased in 8-day old Artemiafed larvae (equal to $D_{0}$ of the moulting cycle), recovering slightly later (Fig. 4). A similar pattern was observed in $O$. sinensis-fed larvae, the decrease occurring somewhat earlier, whereas the later increase was much more obvious because of their prolonged developmental duration. In the zoea II, AEC increased in Artemia-fed larvae throughout larval development. $O$. sinensis-fed larvae showed a similar increase in the AEC, reaching similar values to Artemia-fed larvae at day 11; however, during late premoult of the moulting cycle, AEC declined rapidly from 0.89 to 0.78 . A similar decrease in AEC $(0.85$ to 0.32 ) was observed in the late premoult period of $O$. sinensis-fed megalopa, whereas no differences in the AEC were observed during earlier developmental periods between both nutritional conditions tested. The AEC of Artemia-fed megalopa in Experiment I and II are generally in good agreement, except a decrease to 0.5 on day 12 in Experiment II (recovering three days later to the previous level) and a somewhat lower initial value in Experiment I. Generally the AEC did not reflect the differences between the two nutritional conditions tested. Only in late premoult periods of the moulting cycle could a sharp decrease in AEC be observed when larvae were fed suboptimally with $O$. sinensis.

The differences between the two diets were most obvious when individual contents of adenosine nucleotides were pooled (Fig. 5). The differences between the two nutritional diets are significant, due to the low variation between the three replicates (see above). The individual nucleotide contents reflected the nutritional status of the larvae earlier than changes in the AEC did. 

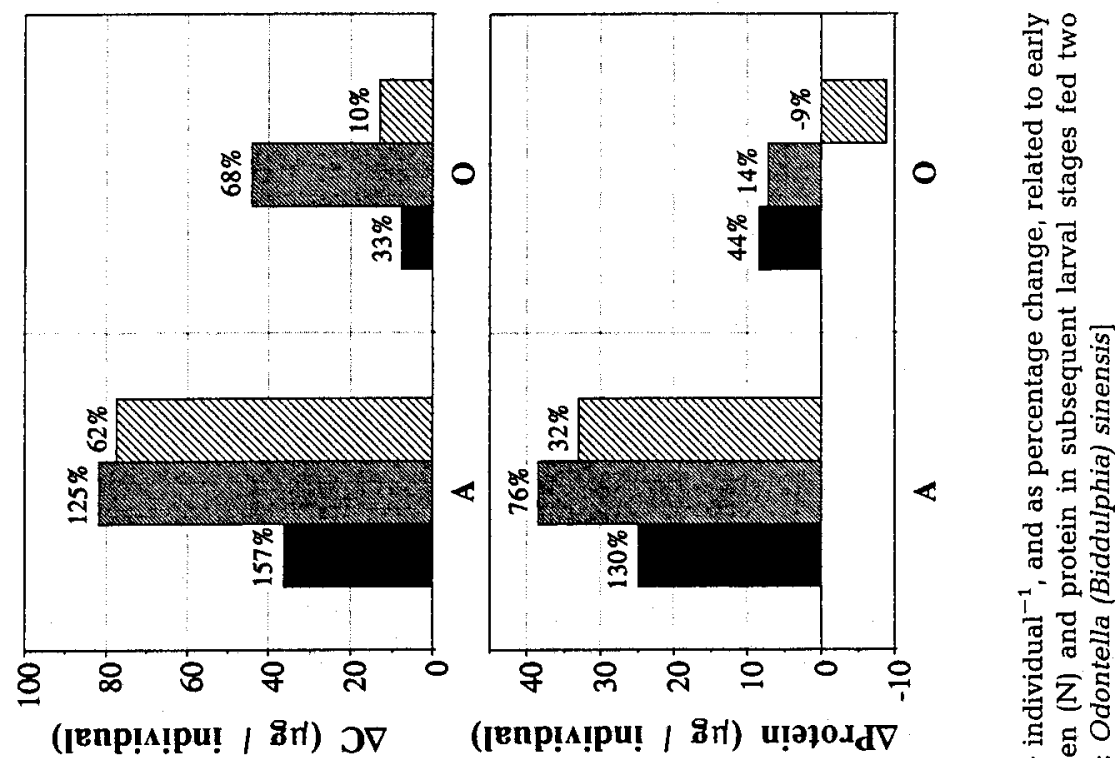
(ןenp!a!pu! / 8n) u!əฺ0גd
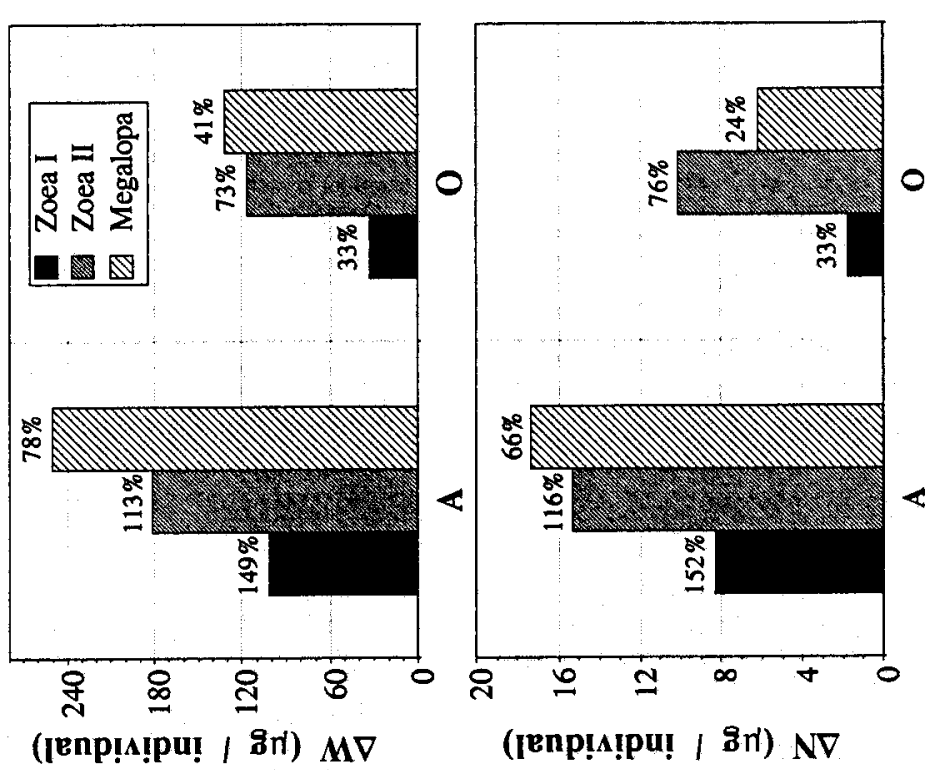

용

至点

बं $\overline{0} \cdot \pi$

क

๑ 용

总苍

$\leq \sum \stackrel{n}{0}$

号若

के

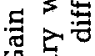

05

เ்

嗃

的

路

त $\Xi$

棺 

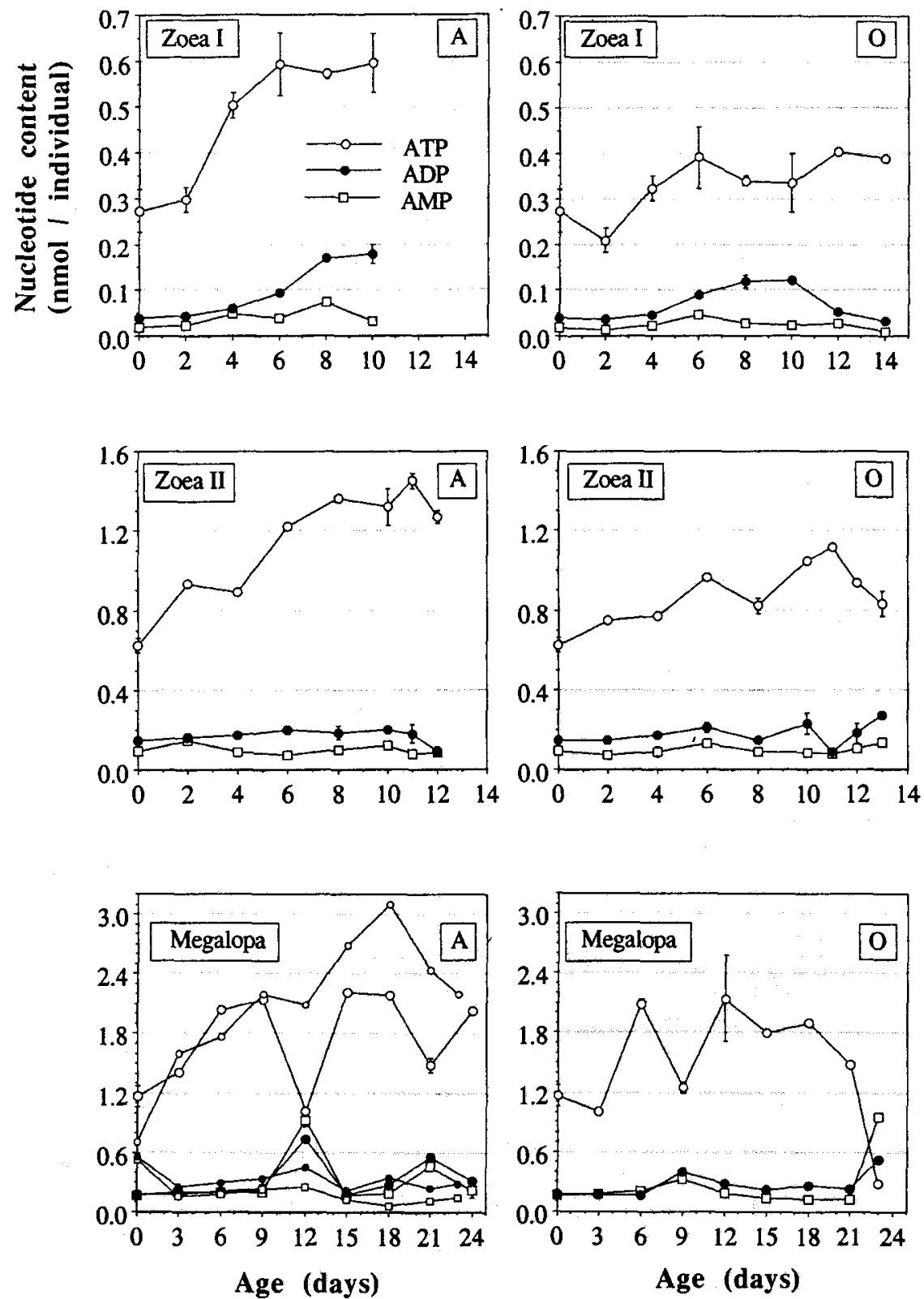

Fig. 3. Hyas araneus. Individual adenylate nucleotide content (ATP, ADP, AMP; $\bar{x} \pm S D, n=3$ ) during the course of the moulting cycle in subsequent larval stages fed two different diets [A: Artemia sp.; O: Odontella (Biddulphia) sinensis]. Results of Experiment I are also shown in the diagram (small signs) 

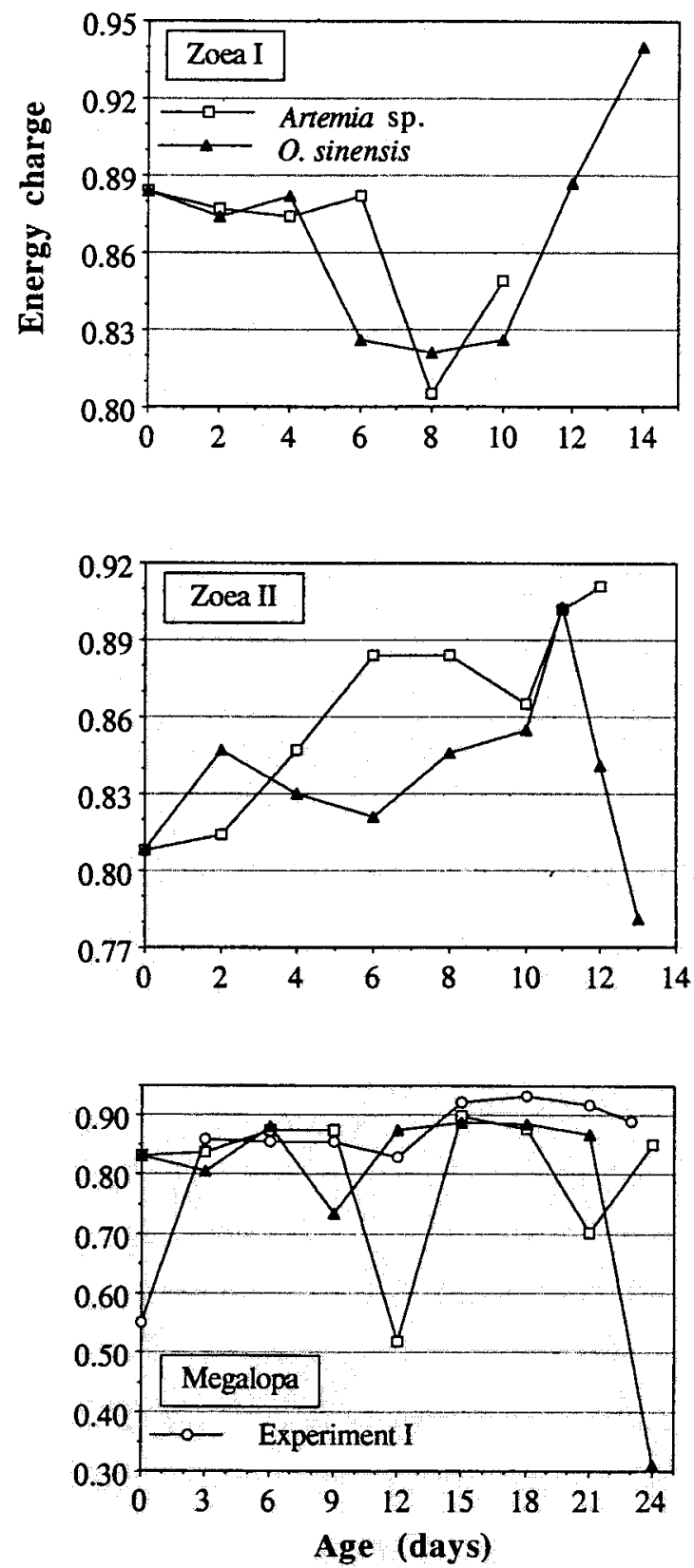

Fig. 4. Hyas araneus Adenylate energy charge (AEC) [(ATP + 1/2ADP)/(ATP + ADP + AMP)] during the course of the moulting cycle in subsequent larval stages fed two different diets. Results of Experiment $I$ are also shown in the diagram 

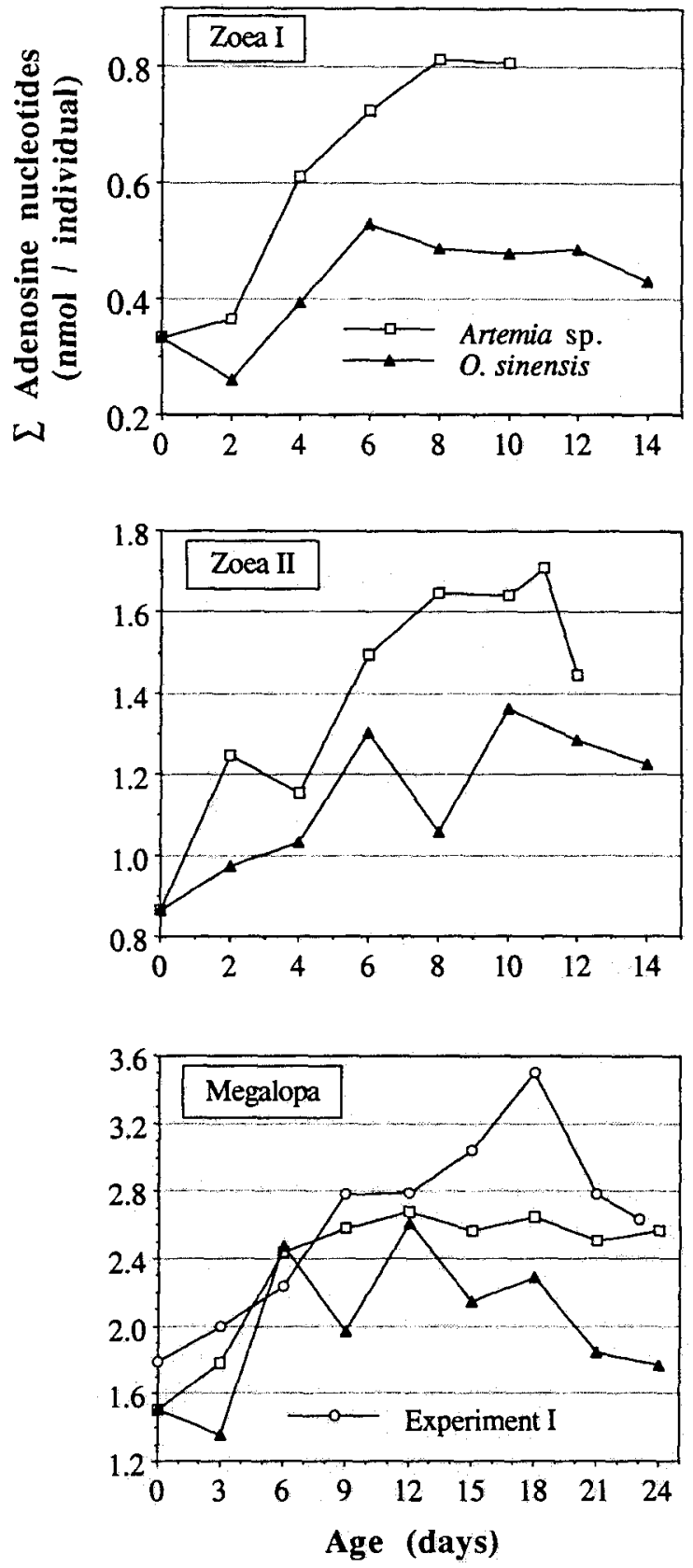

Fig 5. Hyas araneus. Pooled adenylate nucleotide content (ATP + ADP + AMP) during the course of the moulting cycle in subsequent larval stages fed two different diets. Results of Experiment I are also shown in the diagram 
No correlations could be found between the individual content of ATP and one of the other triphosphates, nor between the three triphosphates. Correlation was found between the pooled contents of the three triphosphates CTP, GTP and UTP and the ATP content $\left(\Sigma \mathrm{CTP}+\mathrm{GTP}+\mathrm{UTP}=0.078+0.27 \mathrm{ATP} ; \mathrm{r}=0.85 ; \mathrm{n}=55_{;} \mathrm{P}<0.001\right)$. Instead of using a linear regression, a somewhat better correlation can be found by using a power function $\left(\Sigma \mathrm{CTP}+\mathrm{GTP}+\mathrm{UTP}=-0.47 \mathrm{ATP}^{0.919}, \mathrm{R}=0.919\right)$.

\section{Relationship between growth and nucleotide composition}

The nutritional conditions, as shown above, were reflected both in growth and nucleotide composition. It was found that the content of nucleotides are correlated with the contents of $C$ and protein (Table 3). The weakest correlations were found between the

Table 3. Hyas araneus. Larval stages (zoea I to megalopa); parameter for linear regression $[\mathrm{y}=\mathrm{a}+\mathrm{b}$ $\mathrm{x}$ ] describing relationships between biochemical components $[\mathrm{x}=$ carbon, protein und Joule individual $\left.^{-1}\left(\mathrm{~J}_{\text {ind }}^{-1}\right)\right]$ and nucleotide concentrations $[\mathrm{Y}=\mathrm{ATP}, \Sigma \mathrm{AN}, \Sigma \mathrm{CGU}]$ for pooled data of the two nutritional conditions tested. $\Sigma$ AN: sum of adenosin nucleotides (AMP + ADP + ATP); $\Sigma$ CGU: sum of CTP + GTP + UTP; intercept $a$ and slope $b \pm$ standard deviations, $r$ : correlation coefficient;

level of significance in all cases $\mathrm{P}<0.001$; number of paired data $n=58$, for $\Sigma \mathrm{CGU} n=56$

\begin{tabular}{|c|c|c|c|c|c|c|}
\hline & & a & \pm & b & \pm & I \\
\hline Carbon & $\begin{array}{l}\text { ATP } \\
\Sigma A N \\
\Sigma C G U\end{array}$ & $\begin{array}{l}0.094 \\
0.179 \\
0.087\end{array}$ & $\begin{array}{l}0.081 \\
0.058 \\
0.032\end{array}$ & $\begin{array}{l}0.085 \\
0.011 \\
0.002\end{array}$ & $\begin{array}{l}0.0005 \\
0.0004 \\
0.0002\end{array}$ & $\begin{array}{l}0.905 \\
0.965 \\
0,846\end{array}$ \\
\hline Protein & $\begin{array}{l}\text { ATP } \\
\Sigma A N \\
\Sigma C G U\end{array}$ & $\begin{array}{l}0.150 \\
0.197 \\
0.096\end{array}$ & $\begin{array}{l}0.104 \\
0.081 \\
0.036\end{array}$ & $\begin{array}{l}0.012 \\
0.015 \\
0.003\end{array}$ & $\begin{array}{l}0.0010 \\
0.0008 \\
0.0003\end{array}$ & $\begin{array}{l}0.843 \\
0.935 \\
0.804\end{array}$ \\
\hline $\mathrm{J}$ ind ${ }^{-1}$ & $\begin{array}{l}\text { ATP } \\
\Sigma A N \\
\Sigma C G U\end{array}$ & $\begin{array}{l}0.131 \\
0.232 \\
0.096\end{array}$ & $\begin{array}{l}0.083 \\
0.067 \\
0.032\end{array}$ & $\begin{array}{l}0.234 \\
0.293 \\
0.067\end{array}$ & $\begin{array}{l}0.0150 \\
0.0130 \\
0.0058\end{array}$ & $\begin{array}{l}0.897 \\
0.952 \\
0.842\end{array}$ \\
\hline
\end{tabular}

sum of the three triphosphates CTP, GTP and UTP and the biochemical compounds C and protein. The highest correlation coefficients were found for the relationship between $\Sigma A N$ and $C$ and protein. For these two cases, separate correlations for the two nutritional conditions tested are given in Figure 6 . The correlation constants differed slightly but significantly with the nutritional status of the larvae.

The total weight of the measured adenosine nucleotides amounted to $0.16-0.28 \%$ of $W$, varying only slightly between the larval stages and nutritional conditions. Variation was predominantly observed within the single larval stages, with lowest values $(0.16-0.18 \%)$ on day two or three and slightly higher values $(0.21-0.28 \%)$ during later development.

\section{DISCUSSION}

The two diets tested here have been previously used in a variety of studies to estimate energy budgets of laboratory reared decapod larvae (Harms \& Anger, 1990; Harms et al, 1990a). The algae diet (Odontella [Biddulphia] sinensis) had been found to 

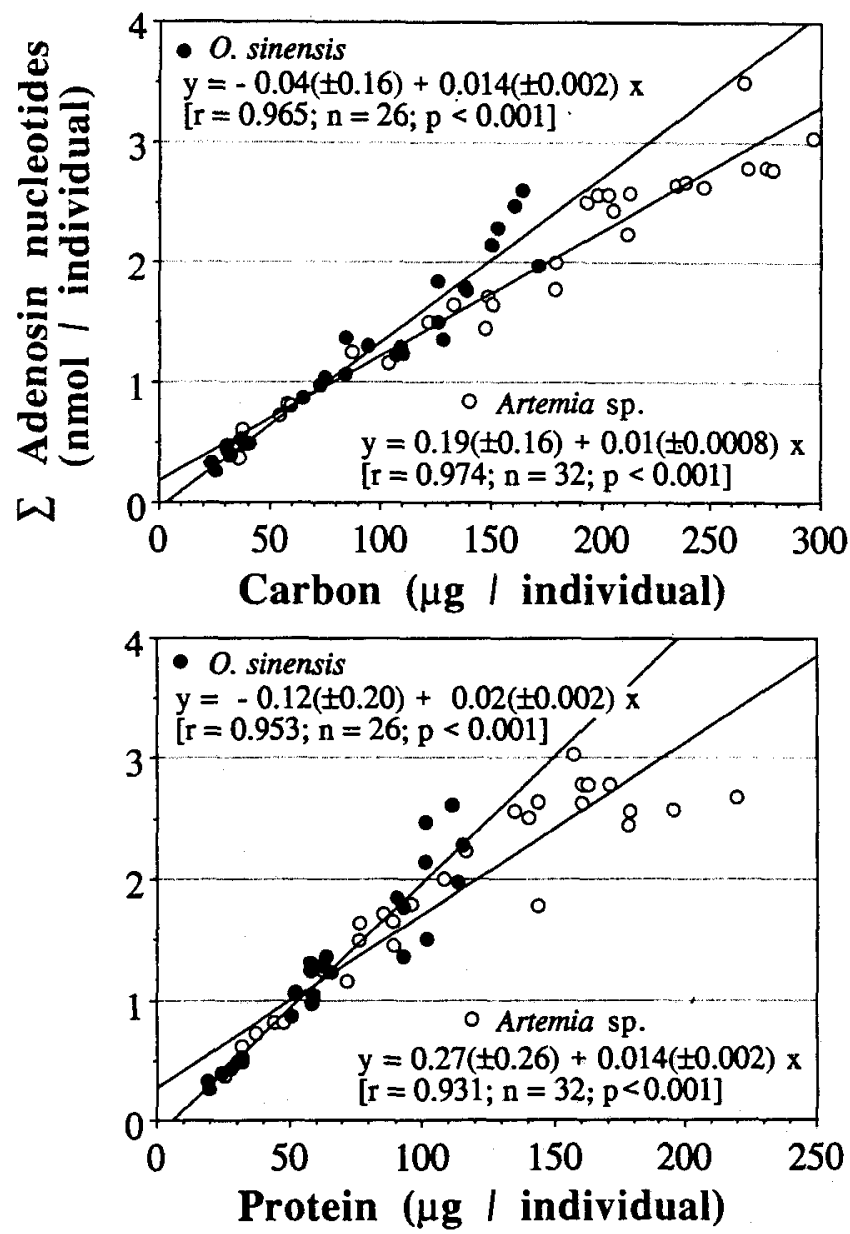

Fig. 6. Hyas araneus. Carbon and protein concentrations related to the adenosine nucleotide pool for the two different nutritional conditions tested. Intercept with $\mathrm{y}$-axis and slope of least-square regression lines given with $95 \%$ confidence intervals; $r$, correlation coefficient; $n$, number of paired data; $P$, level of significance for $r \neq 0$

be sufficient for some further development to the next larval instars (Harms \& Seeger, 1989), but larvae failed to complete the entire development successfully up to the juvenile instar when fed exclusively on this diet. In this study, further development to the next instar could be observed in all cases. Developmental success decreased in $O$. sinensis-fed megalopa, which corresponds to the low increase of the elemental composition $(\mathrm{C}, \mathrm{H}, \mathrm{N})$ and protein content in this larval stage. This study again demonstrates and quantifies the ability of larval crabs to convert phytoplankton biomass (see also Harms et al., 1990a). The growth of $O$. sinensis-fed larvae reported here are higher than in previous experiments (Harms et al., 1990a). The algae diet allowed some net gain in organic constituents, except for protein in the megalopa stage. However, $O$. sinensis supplies suboptimal nutrition compared to Artemia sp. nauplii. 
Decapod larval development is characterized by a sequence of morphologically different instars, which are separated by moults. The time between two moults can be further divided into a series of internal physiological and anatomical alterations, the moulting cycle as described by Drach (1939) and Drach \& Tschernigovtzeff (1967) and which was adapted by Anger (1983) to brachyuran decapod larvae. Major biochemical changes, especially in the nucleotide composition, has been found to take place in late premoult of the moulting cycle. This is especially pronounced when larvae are fed a suboptimal diet (Figs 3,4), indicating that during this period of the moulting cycle, energy consuming processes are taking place.

The AEC is proposed as an index of the energy potentially available for cellular metabolism (Atkinson, 1977; Dickson \& Franz, 1980). Any factor which upsets homeostasis should be reflected in an altered AEC. The maximum value of the AEC is 1, but it is found to be normally maintained between 0.80 and 0.94 in unstressed organisms (Ivanovici, 1980b; Vetter \& Hodson, 1982). The values for the AEC observed here varied with a few exceptions $(O$. sinensis-fed zoea II and megalopa in late premoult stage, and 12-day old Artemia-fed megalopa) within this range, showing that suboptimal feeding conditions are not reflected in the AEC. The maintenance of a high AEC might be the result of rapid extramitochondrial resynthesis of $1 \mathrm{~mol} \mathrm{ATP}$ and $1 \mathrm{~mol}$ of AMP from $2 \mathrm{~mol}$ of ADP by adenylate kinase. The resulting AMP is then rapidly deaminated to inosine monophosphate (Chapman et al., 1976; Driedzic \& Hochachka, 1976). The maintenance of a high AEC in suboptimally fed larvae may facilitate a rapid resumption of synthetic activity when larvae regain access to high quality food.

The individual AN content of Hyas araneus larvae is affected by nutritional conditions at an early stage of the developmental process. This is made most obvious by the pooled AN data (Fig. 5). Similar results had been obsetved in a previous study (Harms et al., 1990b), where decreasing adenylate pools were reported in starving Carcinus maenas larvae while the AEC was maintained constant. Literature reports on changes in ATP contents are contradictory. Decreasing ATP contents were reported for starving adult crayfish Orconectes inermis inermis (Dickson \& Giesy, 1982). However, in contrast to this the same authors reported increasing ATP levels in starved crayfish Procambrus clarkii. Increasing ATP values were also reported for food-deprived fish (Dehn, 1985). Schirf et al. (1987) showed that different organs of starved crayfish $P$. clarkii respond differently to nutritional stress. The ATP pool increased in the muscles although the AEC was unaffected, while it decreased in the hepatopancreas.

Nucleotide concentrations in $H$. araneus larvae reached values between 0.16 to $0.28 \%$ of $\mathrm{W}$. The concentrations found for $C$. maenas larvae were somewhat higher, varying from 0.20 to $0.56 \%$ of $W$ (Harms et al., 1990b). Higher values were reported for North Atlantic krill varying from 0.40 to $1.3 \%$ (Saether \& Mohr, 1987). ATP contribute up to $75-92 \%$ of this weight proportion, which stands in good agreement with the weight relationships reported by Harms et al. (1990) and Saether \& Mohr (1987).

The results presented here show that the AEC was generally unaffected by the two food conditions tested. These findings are not restricted to Decapoda. Vetter et al. (1986) found that AEC was kept constant in fishes, and that the nucleotide content decreased in response to the stress situations. The individual amount of adenylate nucleotide might be a more sensitive indicator of the well-being of organisms. The findings reported here thus support Atkinson's original hypothesis (Atkinson, 1968) that the AEC is a relatively 
conservative property and that changes in AEC are always accompanied if not preceded by changes in the quantity of adenylate nucleotides.

Acknowledgements. I wish to thank B. Meyer and S. Buluscheck for technical assistance in cultivating larvae and Odontella (Biddulphia) sinensis. U. Süssens, S. Torbohm and I. Ulrich helped in the biochemical analyses. My special thanks are due to Dr. S. England for correcting the English. This research was supported by a grant from the Deutsche Forschungsgemeinschaft (Project AN145/2-3) and a postdoctoral grant given by the "Biologische Anstalt Helgoland".

\section{LITERATURE CITED}

Anger, K., 1983. Moult cycle and morphogenesis in Hyas araneus larvae (Decapoda, Majidae) reared in the laboratory. - Helgoländer Meeresunters. 36, 285-302.

Anger, K., Laasch, N., Püschel, C. \& Schorn, F., 1983. Changes in biomass and chemical composition of spider crab (Hyas araneus) larvae reared in the laboratory. - Mar. Ecol. Prog. Ser. 12, 91-101.

Anger, K., Harms, J., Püschel, C. \& Seeger, B., 1989. Physiological and biochemical changes during the larval development of a brachyuran crab reared under constant conditions in the laboratory. Helgoländer Meeresunters. 43, 225-244.

Atkinson, D. E. \& Walton, G. M., 1967. Adenosine triphosphate conservation in metabolic regulation. $-\mathrm{J}$. biol. Chem. 242, 3239-3241.

Atkinson, D. E., 1968. The energy charge of the adenylate pool as a regulatory parameter with feedback modifers. - Biochemistry 7, 4030-4034.

Atkinson, D. E., 1977. Cellular energy metabolism and its regulation. Acad. Press, New York, 293 pp.

Bomsel, J. L. \& Pradet, A., 1967. Study of adenosine 5' mono-, di-, triphosphate in plant tissue. IVRegulation of the level of nucleotides in vivo by adenylate kinase: theoretical and experimental study, - Biochim. biophys. Acta 162, 230-242.

Chapman, A. G., Miller, A. \& Atkinson, D. E., 1976. Role of the adenylate deaminase reaction in regulation of adenine nucleotide metabolism in ehrlich ascites tumor cells. - Cancer Res. 36, $1144-1150$.

Dehn, P. F., 1985. Effects of laboratory holding and short-term nutritional deprivation on energy metabolism of red-ear sunfish, Lepomis microlopus, - Tex. J. Sci. 26S, 67.

Dickson, G. W. \& Franz, R., 1980. Respiration rates, ATP turnover and adenylate energy charge in excised gills of surface and cave crayfish. - Comp. Biochem. Physiol. 65A, 375-379.

Dickson, G. W. \& Giesy, J. P., 1982. The effects of starvation on muscle phosphoadenylate concentration and adenylate energy charge on surface and cave crayfish. - Comp. Biochem. Physiol. 71A, 357-361.

Drach, P., 1939. Mue et cycle d'intermue chez les Crustacés Décapodes. - Annis Inst. océanogr., Monaco 19, 103-391.

Drach, P. \& Tschernigovtzeff, C., 1967. Sur la méthode de la détermination des stades d'intermue et son application générale aux Crustacés. - Vie Milieu (A) 18, 595-610.

Driedzic, W. R. \& Hochachka, P., 1976. Control of energy metabolism in fish white muscle. - Am. J. Physiol. 230, 579-582.

Harms, J. \& Seeger, B., 1989. Larval development and survival in seven decapod species (Crustacea) in relation to laboratory diet. - J. exp. mar. Biol. Ecol. 133, 129-139.

Harms, J. \& Anger, K., 1990. Effects of nutrition (herbivore vs. carnivore) on the energy budget of a brachyuran megalopa. - Thermochim. Acta 172, 229-240.

Harms, J., Anger, K., Klaus, S. \& Seeger, B., 1990a. Nutritional effects on ingestion rate, digestive enzyme activity, growth, and biochemical composition of Hyas araneus L. (Decapoda: Majidae) larvae. - J. exp. mar. Biol. Ecol. 145, 233-265.

Harms, J., Moal, J., LeCoz, J. R., Daniel, J. Y. \& Samain, J. F., 1990b. Nucleotide composition and energy charge in growing and starving zoea I of Carcinus maenas (Decapoda: Portunidae). Comp. Biochem. Physiol. 96B, 404-414.

Ivanovici, A. M., 1980a. The adenylate energy charge in the estuarine mollusc (Pyrazus ebeninus). Laboratory studies of responses to salinity and temperature. - Comp. Biochem. Physiol. 66A, 43-55. 
Ivanovici, A. M., 1980b. Application of adenylate energy charge to problems of environmental impact assessment in aquatic organisms. - Helgoländer Meeresunters. 33, 556-565.

Lowry, O. M., Rosebrough, N. I., Farrant, A. L. \& Randall, R. J., 1951. Protein measurements with the Folin phenol reagent. - J, biol. Chem. 193, 263-275.

Moal, J., Le Coz, J. R., Samain, J. F. \& Daniel, J. Y., 1989. Nucleotides in bivalves: Extraction and analysis by high performance liquid chromatography (HPLC). - Comp. Biochem. Physiol. 93B, 307-316.

Romano, J. C. \& Daumas, R., 1981. Adenosine nucleotide "energy charge" ratios as an ecophysiological index for microplankton communities. - Mar. Biol. 62, 281-296.

Saether, O. \& Mohr, V., 1987. Chemical composition of North Atlantic krill. - Comp. Biochem. Physiol. 88B, 157-164.

Schirf, V. R., Turner, P., Selby, L., Hannapel, C., De La Cruz, P. \& Dehn, P. F., 1987. Nutritional status and energy metabolism of crayfish (Procambarus clarkii, Girard) muscle and hepatopancreas. Comp. Biochem. Physiol. 88A, 383-386.

Vetter, R. D. \& Hodson, R. E., 1982. Use of adenylate concentrations and adenylate energy charge as indicators of hypoxic stress in estuarine fish. - Can. J. Fish. aquat. Sci. 39, 535-541.

Vetter, R. D., Hwang, H.-M. \& Hodson, R. E., 1986. Comparison of glycogen and adenine nucleotides as indicators of metabolic stress in mummichogs. - Trans. Am. Fish. Soc. 115, 47-51. 